Article

\title{
Evolution of Hay Meadows between 1956, 1986, and 2016 and Its Relation to the Characteristics and Location of the Parcels in the Valley of the River Esera (Pyrenees, Spain)
}

\author{
Joaquín Ascaso ${ }^{1}$, Ramón Reiné ${ }^{1, *}$ (D) and Olivia Barrantes ${ }^{2,3}$ (D) \\ 1 Departamento de Ciencias Agrarias y Medio Natural, Escuela Politécnica Superior, Universidad de Zaragoz \\ Ctra Cuarte s/n, 22071 Huesca, Spain; jascaso@unizar.es \\ 2 Departamento de Ciencias Agrarias y Medio Natural, Facultad de Veterinaria, Universidad de Zaragoza \\ Miguel Servet 177, 50013 Zaragoza, Spain; olivia.barrantes@unizar.es \\ 3 Instituto Agroalimentario de Aragón -IA2- CITA-Universidad de Zaragoza, 50013 Zaragoza, Spain \\ * Correspondence: rreine@unizar.es; Tel.: +34-974-232-469
}

Received: 13 January 2020; Accepted: 25 February 2020; Published: 2 March 2020

\begin{abstract}
The uses of the agricultural surface of hay meadows and crops of the mountain areas of the Spanish central Pyrenees are subject to constant transformations. This paper addresses the changes produced in the hay meadows of the Ésera river valley of the central Pyrenees (Spain) regarding the surface and the agronomic and topographic characteristics of the parcels between 1956-1986 and 1986-2016. The cartographed area is 5226 hectares, of which 1941 hectares correspond to 6416 polygons that have been mowed or cultivated on one of the three reference dates. In the period $1956-1986$, there is a reduction in the agricultural area of meadows and crops (13.59\%) in favor of pastures, forest, urbanized land, and water reservoirs. The surface of the meadows increases to $301.58 \%$, to the detriment of the crops, until almost their disappearance. Between 1986 and 2016, the area of meadows is reduced to $59.11 \%$, and the area of pastures, forests, and urbanized land increases. The topographic characteristics of the parcels with respect to surface, altitude, slope, width, and terracing and distance to the communication routes determine mechanized access and management and discriminate the transformation to pasture and forest.
\end{abstract}

Keywords: hay meadow; Pyrenees; temporal evolution surface; crop parcel features

\section{Introduction}

The hay meadows of the Spanish central Pyrenees are used by mowing for hay or silage for winter feeding within the cattle production system. In most cases, they are also grazed in autumn and less frequently at the end of winter [1,2]. Unlike other types of European pastures, they have a relatively close origin in the Middle Ages [3]. They are established as secondary vegetation after deforestation through grazing and mowing and have often been in alternation with agricultural use [4]. Due to their floristic composition, they are considered in the Arrhenatherion elatioris and Triseto-Polygonion bistortae alliances of Arrhenatheretalia elatioris.

The Pyrenees and other mountain regions of Europe have undergone major changes in agricultural uses since the 1950s [5-7]. They affect both the size of the surfaces of the different types of land uses and the location within a specific geographical area and involve a modification of the vegetation and ecosystem. In general terms, these changes imply a decrease in the area of hay meadows and agricultural crops or the intensification of production systems in part of the surface. However, the results of these changes cannot be generalized because they depend on the geographical area and the 
geographic and temporal observation scale [8-12]. In this sense, the area of crop plots and meadows of two valleys may be the same at a given time, but the proportion of the surface of the valley and hillside plots suitable for mechanization may be different. According to the SIGPAC (Geographic Information System for Agricultural Parcels mapping of the Spanish Ministry of Agriculture and Fisheries, Food, and Environment), in the valleys of the Pyrenees are numerous plots $10 \mathrm{~m}$ wide. These plots are not represented at less precise scales than 1:5000. As a consequence, the results of the analysis of changes in land uses will be different according to the topographic scale. It is also necessary to consider that exploitation systems depend on socio-economic factors, in addition to the intrinsic factors linked to mountain areas (such as steep slopes, shallow and unstable soils, abrupt landforms, short vegetative period, low potential productivity, etc.). The most relevant are the variations in time of the agricultural and livestock markets, mechanization, ownership and management of the land, the application of agricultural policy, the competition of land prices with respect to urbanization, the availability of hand of work, the implantation of reservoirs for the production of electrical energy, etc. [13-16].

Most of the literature related to mountain areas in Europe associates changes in the use of hay meadows with variations in flora [17,18], ecosystem diversity [19-22], regeneration of forest communities [23,24] or the effects of climatic variations [25-27]. However, studies that link changes in the use of hay meadows that support the winter feeding of cattle with the variation of the forage area and the agronomic conditions that determine them are less common. This has an impact on the availability (loss) and spatial distribution of own resources of non-intensified livestock systems [28,29] against European guidelines and recommendations [30]. In this regard, the European Union has established a series of measures aimed at maintaining agro-livestock activity and the conservation of hay meadows through the CAP (Common Agricultural Policy) [31-33]. Likewise, Council Directive 92/43/EEC (European Economic Community) considers these meadows as natural habitats of interest (6510 and 6520), and the Natura 2000 Network establishes the need for their conservation and the definition of specific geographical areas [34].

The evaluation of the evolution of mountain hay meadows, and the livestock production systems to which they are associated, must be multidisciplinary and at different scales for the purposes of the CAP 2021-2027 application and conservation policy. Within this strategy, this work is proposed whose objective is the quantification of the evolution of the areas of hay meadows and the relationship with environmental and agronomic factors from 1956 to 1986 and from 1986 to 2016 in the Ésera River valley of the central Spanish Pyrenees. The choice of the study area is motivated by the importance of the surface of the hay meadows within the mountain livestock production system and is representative of the changes that have occurred in recent decades.

\section{Materials and Methods}

\subsection{Area of Study}

The area of study is in the valley of the Ésera river in the Pyrenees, in the province of Huesca (Spain). It occupies an area of 5226 ha between 900 and $1700 \mathrm{~m}$ and includes the Río Ésera SCI (Natura 2000 Network, ES2410046) of 1759 ha (Figure 1). It is a valley with glacial and river morphology excavated on Paleozoic materials. Hay meadows are found on quaternary deposits of moraines, hillside landslides, alluvial terraces, and even in the flood plain. In some cases, they are on parcels with terraces made of stone wall.

In the altitudinal range considered, the data of the weather station of the town of Benasque (1140 $\mathrm{m}$ ) show an average annual rainfall of $1144 \mathrm{~mm}$, with November as the month with the highest rainfall $(144 \mathrm{~mm})$ and March with the lowest $(65 \mathrm{~mm})$. The average annual temperature is $9.3^{\circ} \mathrm{C}$, the coldest month is January $\left(1.0^{\circ} \mathrm{C}\right)$, and the warmest is July $\left(18.9^{\circ} \mathrm{C}\right)$. The forest vegetation is forests of Pinus sylvestris, Quercus faginea or mixed with Betula pendula, Populus tremula, Tilia platyphyllos, Fraxinus excelsior, etc. Hay meadows are secondary communities of Arrhenatherion elatioris and Triseto-Polygonion bistortae that, in some cases, have been crop fields or were planted with forage species before the 1970s. 

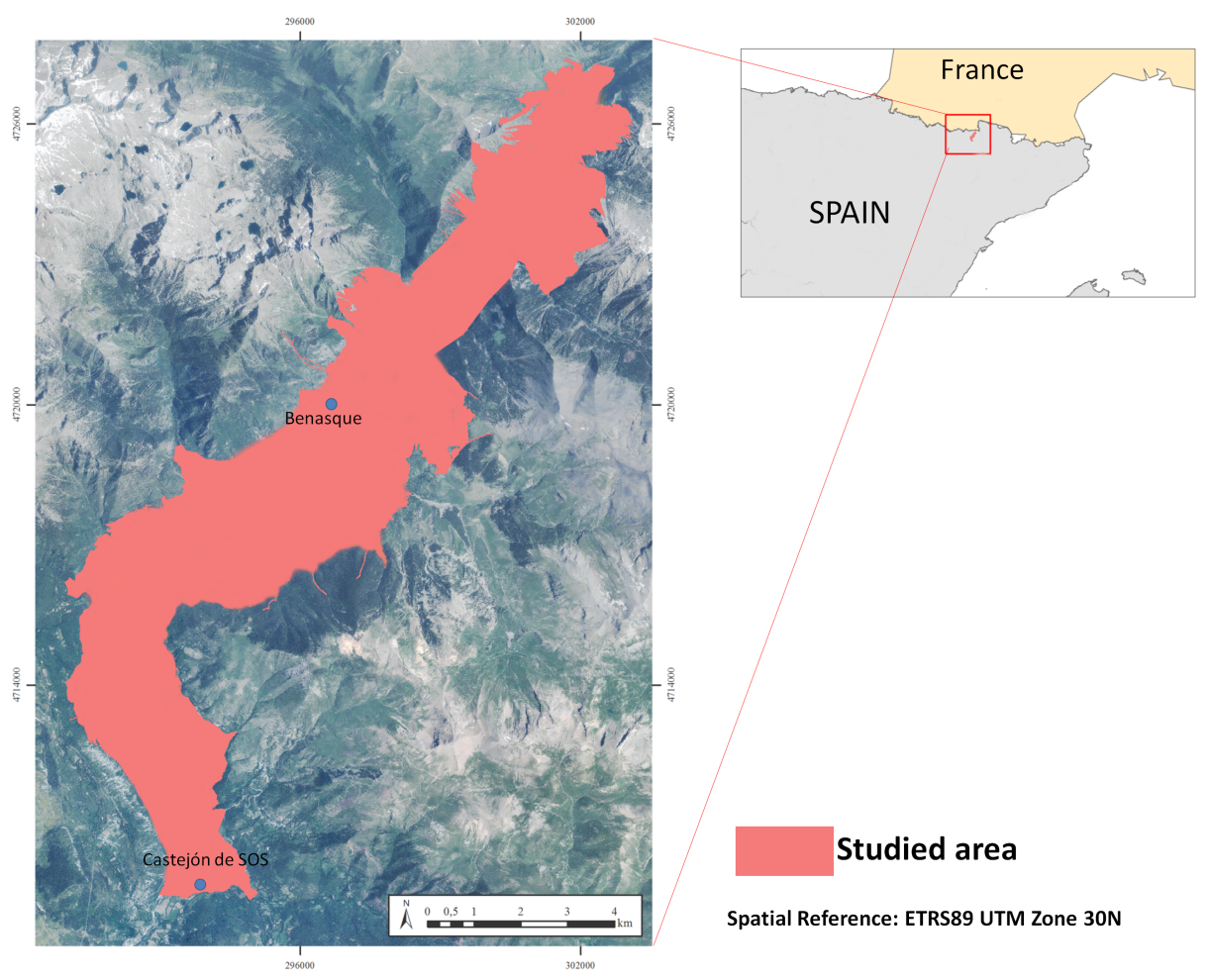

Spatial Reference: ETRS89 UTM Zone 30N

Figure 1. Location of studied area.

\subsection{Cartography}

The mapping has been made from the aerial photography of 1956, 1986, and 2016 of the National Geographic Institute. The first two have been orthogonalized and georeferenced from the frames while the last are georeferenced orthophotographs. In addition, the SIGPAC mapping of the Ministry of Agriculture and Fisheries, Food, and Environment of 2016 has been used. The basic work scale is $1: 10,000$, and the minimum area of representation is 0.25 ha and 0.0625 ha in irregular geometry parcels. The polygons have been drawn on the cartography of each of the reference years 1956, 1986, and 2016. The computer software used is ArcGIS 10.5(Environmental System Research Institute, Inc., Redlands, CA, USA). The categories of land uses manually attributed to each polygon and year through photointerpretation are: 1 Meadow, 2 Pasture, 3 Crop, 4 Unproductive, 5 Forest, 6 Urbanized area, 7 Reservoir, 8 Communication route, and 9 Riverbed. It is complemented by review of the polygons in the field, with the statements of the SIGPAC 2016 and with interviews with farmers.

The following parameters have been associated to each cartographic polygon: Polygon surface (ha), Minor polygon diameter $(\mathrm{m})$, Altitude $(\mathrm{m})$, Slope $\left({ }^{\circ}\right)$, EW orientation index (AspEW), NS orientation index (AspNS), Potential radiation $\left(\mathrm{kWh} / \mathrm{m}^{2}\right.$ year), Distance to communication routes, and Terrace and Contiguity with pasture and forest polygons. The surface of the polygon, the smallest diameter of the polygon (maximum length of the axis perpendicular to the major axis) and the contiguity with pasture and forest polygons have been obtained from the GIS (Geographic Information System). The Distance to the communication pathways has been measured as the shortest distance to the communication pathways for motor vehicles in 1956, 1986, and 2016 from the mapping. The altitude, slope, orientation, and potential radiation have been obtained from the Digital Terrain Model (DTM) of $20 \mathrm{~m}$ of IDEARAGÓN [35]. The orientation of each polygon has been transformed into the AspNS and AspEW indices, corresponding to the cosine and sine of the angle [36]. AspNS and AspEW values range between 1 and -1 and indicate the position between $\mathrm{N}$ and $\mathrm{S}$ and between $\mathrm{E}$ and $\mathrm{W}$, respectively). The presence of a built terrace has been assigned in the photointerpretation.

Comparisons of the characteristics of the meadow and crop parcels within the same year and of the changes in use between different years have been made using the t-Student tests with the 
Levene and chi-square test for quantitative and qualitative variables, respectively (SPSS Statistics 26.0, International Business Machines Corporation, Armonk, NY, USA).

\section{Results}

The results are presented in four sections. The first two correspond to the surfaces of each land use and to the characteristics of the fields of meadows and crops. In the third, the changes of use are exposed in time; in the fourth, the relationship between changes in the use of meadows and crops and the characteristics of the parcels.

\subsection{Land Use Surfaces by Years}

Eight thousand, five hundred and sixty-nine polygons representing 5225.93 ha corresponding to 9 land uses have been mapped in 1956, 1986, and 2016 (Table 1, Figures 2-4). In all three scenarios, the use with the largest area corresponds to forest (between $43.50 \%$ and $55.60 \%$ ). In 1956, the meadows, crops, and pastures occupy $10.50 \%, 26.30 \%$, and $13.04 \%$. In 1986 , the meadows are $31.67 \%$, the pastures $14.73 \%$, and the crops have almost disappeared with $0.13 \%$ of the surface. Finally, in 2016, the meadows represent $18.72 \%$, the pastures $15.06 \%$, and the crops are kept residual with $0.04 \%$ of the total. The rest of the land uses have proportions of less than $5 \%$.

Table 1. Area of land uses in the years 1956, 1986, and 2016 of the mapped area.

\begin{tabular}{cccc}
\hline Land use & \multicolumn{3}{c}{ Surface (ha) } \\
\hline Years & $\mathbf{1 9 5 6}$ & $\mathbf{1 9 8 6}$ & $\mathbf{2 0 1 6}$ \\
\hline Meadow & 548.78 & 1655.02 & 978.29 \\
Pasture & 681.47 & 769.53 & 786.77 \\
Crop & 1374.62 & 6.96 & 2.25 \\
Unproductive & 2.31 & 3.91 & 5.92 \\
Forest & 2273.52 & 2357.96 & 2905.58 \\
Urbanized area & 35.39 & 76.81 & 196.04 \\
Reservoir & 0.00 & 51.46 & 52.99 \\
Communication route & 92.41 & 92.54 & 95.34 \\
Riverbed & 217.43 & 211.75 & 202.76 \\
\hline Total & 5225.93 & 5225.93 & 5225.93 \\
\hline
\end{tabular}

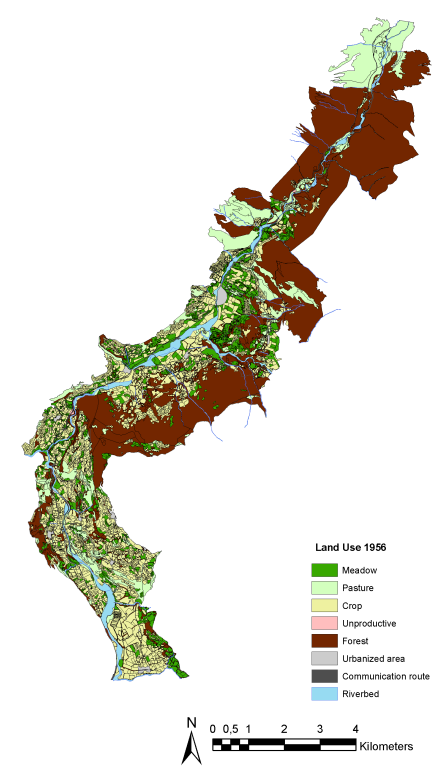

Figure 2. Land uses in 1956. 


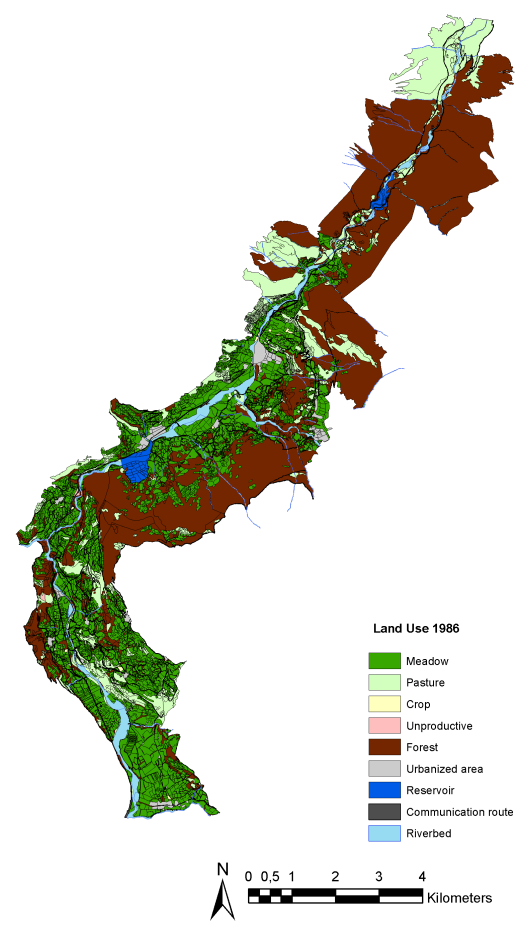

Figure 3. Land uses in 1986.

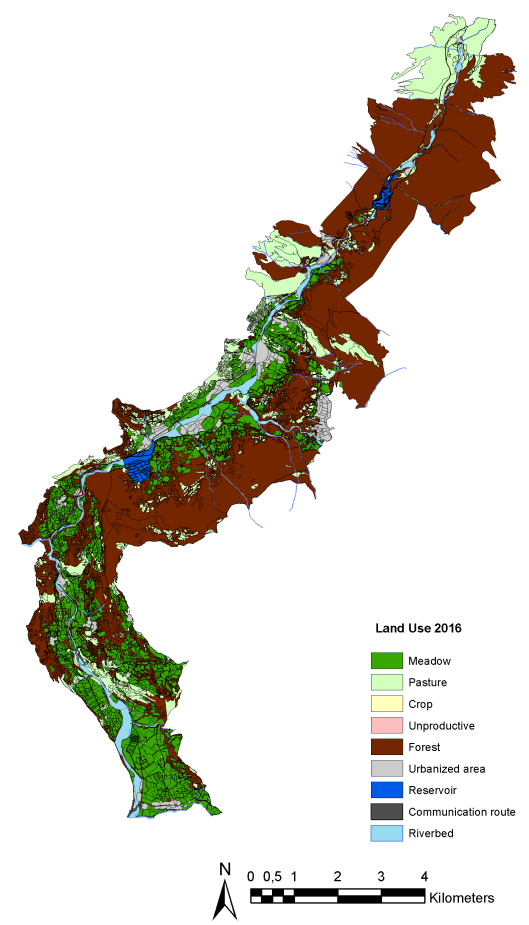

Figure 4. Land uses in 2016.

\subsection{Characterization of the Fields of Meadows and Crops}

Of the 5225.93 ha mapped, there are 6416 polygons that, in one of the three reference dates, have been a hay meadow or cultivation and that represent 1941.00 ha. The characteristics of the variables considered of the meadow and crop polygons of 1956 and 1986 and of the meadow in 2016 are shown synthetically in Table 2. The 2016 crops are not included because they are considered residual ( 2.25 ha in 7 polygons). 
As can be seen, the meadow and crop parcels have values within the same range for all the variables considered. However, comparisons of each variable of the meadow and crop polygons of the same year using the t-Student and chi-square test (Table 2) show significant differences. In 1956, there are significant differences that indicate that the meadows have higher altitude, slope, AspEW (more to the E), lower AspNS (more to the S), and potential radiation and less amount of parcels with terraces. On the contrary, there is no difference in surface area, minor diameter, distance to the communication roads, and contiguity with pasture and forest polygons. In 1986, the significant differences indicate that it is also the meadows that have the highest altitude and slope and, in addition, greater distance to the communication routes and greater proportion of contiguity with pasture and forest polygons.

Table 2. Characteristics and comparison of the meadow and crop parcels of 1956 and 1986 and the 2016 meadow. $t$-Student test for the quantitative variables and chi square for the qualitative variables between the meadow and crop parcels in 1956 and 1986 ( $n=$ number of the parcels).

\begin{tabular}{|c|c|c|c|c|c|c|}
\hline \multirow[b]{2}{*}{ Variables } & \multicolumn{6}{|c|}{1956} \\
\hline & \multicolumn{2}{|l|}{ Meadow } & \multirow{2}{*}{$\begin{array}{l}\text { Crop } \\
\text { Mean }\end{array}$} & \multicolumn{3}{|c|}{$\begin{array}{l}\text { Meadow vs. } \\
\text { Crop }\end{array}$} \\
\hline Quantitative & Mean & SD & & SD & Sig. t-Student & Levene \\
\hline Superface (ha) & 0.31 & 0.46 & 0.30 & 0.43 & ns & (a) \\
\hline Minor polygon diameter $(\mathrm{m})$ & 25.09 & 19.21 & 26.08 & 18.94 & ns & (a) \\
\hline Altitude $(\mathrm{m})$ & 1159.77 & 123.42 & 1144.87 & 155.60 & $* * *$ & (a) \\
\hline Slope $\left({ }^{\circ}\right)$ & 17.32 & 8.93 & 16.30 & 9.82 & $* * *$ & (a) \\
\hline AspEW & -0.10 & 0.63 & -0.21 & 0.63 & $* * *$ & (a) \\
\hline AspNS & -0.08 & 0.63 & -0.04 & 0.60 & * & (a) \\
\hline Potential radiation $\left(\mathrm{KWh} / \mathrm{m}^{2}\right.$ year $)$ & 1298.25 & 43.02 & 1305.49 & 43.40 & $* * *$ & (a) \\
\hline Distance routes $(\mathrm{m})$ & 86.85 & 94.23 & 92.29 & 101.31 & ns & (a) \\
\hline Qualitative & no & yes & no & yes & Sig. chi square & \\
\hline Terrace & 1748 & 12 & 3623 & 982 & $* * * *$ & \\
\hline \multirow[t]{3}{*}{ Contiguity pasture and forest } & $\begin{array}{c}849 \\
\mathrm{n}=1760\end{array}$ & 911 & $\begin{array}{c}2297 \\
\mathrm{n}=4605\end{array}$ & 2308 & ns & \\
\hline & \multicolumn{6}{|c|}{1986} \\
\hline & \multicolumn{2}{|l|}{ Meadow } & \multicolumn{2}{|l|}{ Crop } & \multicolumn{2}{|l|}{$\begin{array}{l}\text { Meadow vs. } \\
\text { Crop }\end{array}$} \\
\hline Quantitative & Mean & SD & Mean & SD & Sig. t-Student & Levene \\
\hline Superface (ha) & 0.30 & 0.45 & 0.26 & 0.24 & ns & (a) \\
\hline Minor polygon diameter $(\mathrm{m})$ & 26.01 & 19.34 & 28.76 & 15.12 & ns & (a) \\
\hline Altitude $(\mathrm{m})$ & 1141.35 & 148.71 & 1047.96 & 121.83 & $* *$ & (a) \\
\hline Slope $\left({ }^{\circ}\right)$ & 15.47 & 8.98 & 5.74 & 3.88 & $* * *$ & (a) \\
\hline AspEW & -0.20 & 0.62 & -0.18 & 0.53 & ns & (a) \\
\hline AspNS & -0.02 & 0.62 & 0.09 & 0.56 & ns & (a) \\
\hline Potential radiation $\left(\mathrm{kWh} / \mathrm{m}^{2}\right.$ year $)$ & 1305.51 & 42.82 & 1307.20 & 24.09 & ns & (a) \\
\hline Distance routes $(\mathrm{m})$ & 88.94 & 100.91 & 28.74 & 15.39 & ** & (a) \\
\hline Qualitative & no & yes & no & yes & Sig. chi square & \\
\hline Terrace & 4845 & 601 & 27 & 0 & $\mathrm{~ns}$ & \\
\hline Contiguity pasture and forest & $\begin{array}{c}2265 \\
\mathrm{n}=5446\end{array}$ & 3181 & $\begin{array}{c}22 \\
\mathrm{n}=27\end{array}$ & 5 & $* * *$ & \\
\hline \multicolumn{7}{|c|}{2016} \\
\hline \multicolumn{7}{|c|}{ Meadow } \\
\hline Quantitative & Mean & SD & & & & \\
\hline Superface (ha) & 0.41 & 0.57 & & & & \\
\hline Minor polygon diameter $(\mathrm{m})$ & 32.49 & 21.89 & & & & \\
\hline Altitude $(\mathrm{m})$ & 1099.43 & 143.97 & & & & \\
\hline Slope $\left({ }^{\circ}\right)$ & 11.06 & 7.01 & & & & \\
\hline AspEW & -0.25 & 0.57 & & & & \\
\hline AspNS & 0.04 & 0.60 & & & & \\
\hline Potential radiation $\left(\mathrm{kWh} / \mathrm{m}^{2}\right.$ year $)$ & 1307.58 & 37.29 & & & & \\
\hline Distance routes $(\mathrm{m})$ & 62.43 & 51.97 & & & & \\
\hline Qualitative & no & yes & & & & \\
\hline Terrace & 2335 & 69 & & & & \\
\hline Contiguity pasture and forest & $\begin{array}{c}925 \\
\mathrm{n}=2404\end{array}$ & 1479 & & & & \\
\hline
\end{tabular}

Sig: significance levels; $\left(^{*}\right)=p<0.05,\left({ }^{* *}\right)=p<0.01,\left({ }^{* * *}\right)=p<0.001$, ns $=$ not significant. Test Levene (a) Equal variances are assumed. 
Another aspect to consider is the geometry of the parcels in relation to the presence or not of the terrace. The comparison of the parcels with and without a terrace that in 1956 were meadows and crops according to the area and minor diameter shows significant differences ( $\mathrm{t}$-Student test, $p=0.000$ ). Those with a terrace have smaller surface averages ( 0.16 ha vs. $0.33 \mathrm{ha})$ and a minor diameter $(19.02 \mathrm{~m}$ vs. $26.06 \mathrm{~m})$.

\subsection{Evolution of Land Use Surface}

Changes and persistence of land uses in the periods 1956-1986 and 1986-2016 are shown in surface area (ha) and in proportion of surface area with respect to the beginning of the interval in Tables S1 and S2 (Supplementary Data). Persistence of use, decreases, and increases can be observed for different uses. The net balance of the area of the meadows increases between 1956 and 1986 to $301.58 \%$ and decreases to $59.11 \%$ between 1986 and 2016. The crops, which in 1956 have an area 2.51 times greater than the meadows, are residuals in 1986 (7 ha) and 2016 ( 2 ha). The area of pasture $(112.92 \%$ and $102.24 \%$ ) and forest (103.71\% and $123.22 \%$ ) have an increasing trend in the two periods considered. The urbanized surface also has the same tendency but in a more pronounced way with a proportion of $217.02 \%$ in 1986 compared to 1956 and $255.22 \%$ in 2016 compared to 1986 . The areas occupied by water reservoirs appear between 1956 and 1986, and they remain stable in 2016. Finally, the lands considered unproductive and the communication routes both increase their surface and that of the riverbed decreases. Synthetically, the most relevant net changes from 1956 to 1986 are the increase in meadows, the decrease in crops, the increase in urbanized areas and the appearance of reservoirs, and, from 1986 to 2016, the decrease in meadows and crops and the increase of urbanized areas.

When considering the meadows between 1956 and 1986, it is observed that $83.64 \%$ is maintained and $85.90 \%$ of the cultivation area is transformed into a hay meadow. There is also a transition to pasture $(6.91 \%)$ and to forest $(4.64 \%)$ and, conversely, and to a lesser extent, from pasture and forest to meadow $(2.15 \%$ and $0.02 \%)$. The crops are reduced to 6.96 ha and, in addition to their transformation to grassland, they pass to pasture $(6.45 \%)$ and forest $(3.69 \%)$. The increase in urbanized area and reservoirs occurs on meadow land $(2.64 \%$ and $1.41 \%)$ and cultivation $(1.97 \%$ and $1.59 \%)$ and, in the case of reservoirs, to the detriment of forest surface and riverbeds.

In the period 1986 to 2016, there is a reduction to $59.11 \%$ of the area of meadows of 1986 . Of the area of meadows of $1986,58.58 \%$ is maintained and $23.77 \%$ is transformed into forest, $11.12 \%$ to pasture, and $6.04 \%$ to urbanized land. The rest of the changes are less important, and the cultivation area is anecdotal with 2.25 ha. It should also be noted that $20.35 \%$ of the pasture area has been transformed into forest.

\subsection{Analysis of Changes or Persistence of Meadows and Crops and the Characteristics of the Parcels}

The most relevant land use changes that affect meadows and crops are pasture, forest, urbanized land, and reservoirs. The increase in urbanized area and reservoirs is due to factors related to tourism and industry and, therefore, is not linked to agronomic factors. The three most important change scenarios that depend on agronomic factors are the transformation of crops to meadows and meadows to pasture and forest between 1956 and 1986 and, finally, from meadow to pasture and forest between 1986 and 2016. The following offers the analysis of the three transformations based on the characteristics of the parcels.

3.4.1. Comparison of the Characteristics of the 1956 Crop Parcels That Have Changed to Meadows versus Those That Have Been Transformed to Pasture and Forest in 1986

Of the 4605 cultivated parcels mapped in 1956 and in 1986, they have been transformed into meadow $3880(84 \%)$ and pasture and forest $635(14 \%)$. The comparison of the cultivation parcels that have been transformed into a meadow with respect to those that have been made to pasture and forest shows significant differences in all the variables (Tables 3 and 4). The meadows have upper averages in surface, minor diameter, orientation to the $\mathrm{N}$ and potential radiation, and smaller in altitude, slope, 
orientation $\mathrm{W}$, and distance to the communication routes. The presence of a terrace on the parcel also presents significant differences and is mostly among the crops that have been transformed into pasture and forest than those that have made it into a meadow. The contiguity with polygons of pasture and forest does not show differences in the change to meadow or pasture and forest.

Table 3. Characteristics and comparison of the parcels that have been transformed into a meadow or pasture and forest in the different scenarios. Quantitative variables expressed in mean.

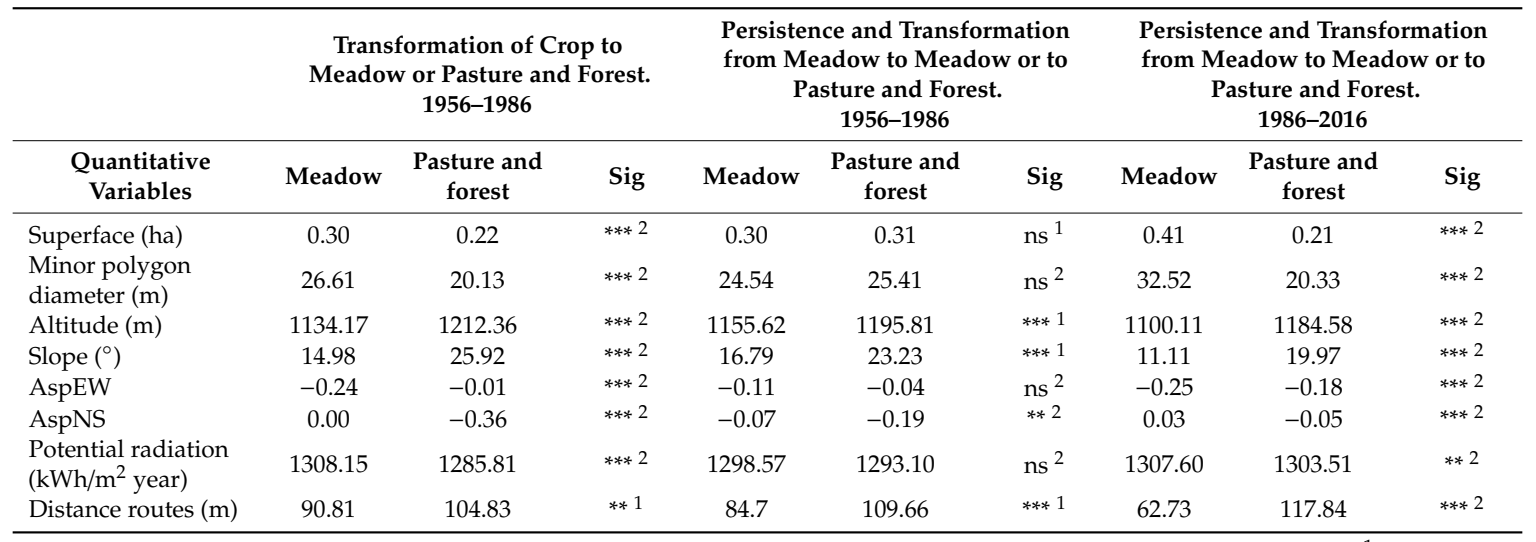

Sig: significance based on t-Student test: $\left(^{* *}\right)=p<0.01,\left({ }^{* * *}\right)=p<0.001$, ns $=$ not significant. Levene test: $\left({ }^{1}\right)$ Equal variances are assumed $\left({ }^{2}\right)$ Equal variances are not assumed.

Table 4. Characteristics and comparison of the number of the parcels (n) that have been transformed or not into a meadow or pasture and forest in the different scenarios. Qualitative variables.

\begin{tabular}{|c|c|c|c|c|c|c|c|}
\hline \multirow[b]{2}{*}{$\begin{array}{c}\text { Qualitative } \\
\text { Variable }\end{array}$} & & \multicolumn{2}{|c|}{$\begin{array}{c}\text { Transformation of Crop to } \\
\text { Meadow or Pasture and } \\
\text { Forest. } \\
\text { 1956-1986 }\end{array}$} & \multicolumn{2}{|c|}{$\begin{array}{c}\text { Persistence and } \\
\text { Transformation from } \\
\text { Meadow to Meadow or to } \\
\text { Pasture and Forest. } \\
\text { 1956-1986 }\end{array}$} & \multicolumn{2}{|c|}{$\begin{array}{c}\text { Persistence and } \\
\text { Transformation from } \\
\text { Meadow to Meadow or to } \\
\text { Pasture and Forest. } \\
\text { 1986-2016 }\end{array}$} \\
\hline & & no & yes & no & yes & no & yes \\
\hline \multirow{4}{*}{ Terrace } & Meadow & 3286 & 594 & 1509 & 7 & 2311 & 68 \\
\hline & Pasture and forest & 247 & 388 & 200 & 5 & 2227 & 520 \\
\hline & Sig & \multicolumn{2}{|c|}{$* * *$} & \multicolumn{2}{|c|}{$* *$} & \multicolumn{2}{|c|}{$* * *$} \\
\hline & $\mathrm{n}$ & \multicolumn{2}{|c|}{3880} & \multicolumn{2}{|c|}{1516} & \multicolumn{2}{|c|}{2379} \\
\hline \multirow{4}{*}{$\begin{array}{l}\text { Contiguity } \\
\text { pasture and } \\
\text { forest }\end{array}$} & Meadow & 1900 & 1980 & 743 & 773 & 908 & 1471 \\
\hline & Pasture and forest & 330 & 305 & 77 & 128 & 1124 & 1623 \\
\hline & Sig & \multirow{2}{*}{\multicolumn{2}{|c|}{$\begin{array}{c}\text { ns } \\
635\end{array}$}} & \multirow{2}{*}{\multicolumn{2}{|c|}{205}} & \multirow{2}{*}{\multicolumn{2}{|c|}{2747}} \\
\hline & $\mathrm{n}$ & & & & & & \\
\hline
\end{tabular}

Sig: significance based on chi square test: $\left(^{*}\right)=p<0.05,\left({ }^{* *}\right)=p<0.01,\left({ }^{* * *}\right)=p<0.001$, ns $=$ not significant.

3.4.2. Comparison of the Characteristics of the 1956 Meadow Parcels That Have Been Maintained as a Meadow against Those That Have Been Transformed into Pasture and Forest in 1986

One thousand, seven hundred and sixty of parcels in 1956 meadow mapped have remained in 1986 as meadow $1516(86 \%)$ and have evolved to pasture and forest $205(12 \%)$. The comparison of meadow parcels that have remained as a meadow with respect to those that have been transformed into pasture and forest shows significant differences in some of the variables (Tables 3 and 4). The meadows that have been maintained present upper averages in $\mathrm{N}$ orientation and are lower in altitude, slope, and distance to the communication routes. The presence of terrace and the contiguity with polygons of pasture and forest of the parcel also present significant differences and are the majority among the meadows that have been transformed into pasture and forest compared to those that have remained as a meadow. On the contrary, the variables surface, minor diameter, orientation $\mathrm{W}$, and potential radiation have no relation. 
3.4.3. Comparison of the Characteristics of the 1986 Meadow Parcels That Have Been Maintained as a Meadow against Those That Have Been Transformed into Pasture and Forest in 2016

Of the 5446 meadow parcels mapped in 1986, 2379 (44\%) have been maintained in 2016, and $2747(50 \%)$ have evolved into pasture and forest. Among them, significant differences are observed (Tables 3 and 4) in the characteristics of the parcels. Those that have been maintained as a meadow have upper averages in surface area, minor diameter, AspNS, potential radiation and are lower in altitude, slope, AspEW, and distance to the communication routes. There are also significant differences in the presence of a terrace that indicate a greater proportion in those that are transformed into pasture and forest and those that are contiguous with pasture and forest polygons that have a greater proportion in those that remain as a meadow.

\section{Discussion}

The area corresponding to meadows and crops in the studied area has suffered a progressive decrease with respect to 1956 of $13.59 \%$ in 1986 and $49.02 \%$ in 2016 . This reduction is linked to exogenous factors derived from changes in the productive and market systems $[13,37,38]$, to the adaptation of the productive systems to the characteristics of the environment, and to the dynamics of the farms themselves (size, labor, capitalization capacity, inheritance, etc.) that are not contemplated here [1,39-42]. This phenomenon is not exclusive and is recognized in other mountain agro-livestock areas $[14,23,43-47]$. Conversely, there has been an increase in the area of forest, pasture, urbanized land, and reservoirs for hydroelectric purposes. The increase in urbanized area and reservoirs is not linked to agronomic factors. However, it should be noted that it occurs mostly at the cost of parcels of meadows and crops of optimal agronomic characteristics located in the valley bottoms and close to the communication routes.

- 1956-1986

Regarding the changes between 1956 and 1986, within the aforementioned context of loss of agricultural land, the drastic reduction of crops and the increase of hay meadows stand out. Most of the fields are transformed into meadows (85.90\%) and $10.14 \%$ are transformed into pasture and forest ( $6.45 \%$ to pasture and $3.69 \%$ to forest). It can also be noted that, in the same period, $83.64 \%$ of the existing meadows remain, but $11.60 \%$ is transformed into pasture and forest $(6.91 \%$ in pasture and $4.69 \%$ in forest). Consequently, the net balance of the area of the meadows increases between 1956 and 1986 to $301.58 \%$, and the crops, which in 1956 have an area 2.51 times greater than the meadows, are residual in 1986 (7 ha).

In the period 1956-1986, the growth in the area of the meadows is linked to the increase in feed cattle fed in winter with hay and decrease in sheep, mule, and agricultural self-consumption [37,39,40,48,49]. At the same time, there is the transition from manual labor and transportation with horses to mechanization of forage production (tractor, mower, and baler). However, this phenomenon does not coincide, for the same period, with other valleys of the Pyrenees. According to Mottet et al. [43], the initial proportion between cultivation and meadow is much smaller (0.2), and there is a decrease in the area of hay meadow to $56 \%$ (mainly in the $60 \mathrm{~s}$ and $70 \mathrm{~s}$ ). In other valleys [49,50], there is a substantial reduction in the meadows between 1935 and 1970. It should be noted that, in the case of the French Pyrenees, the transformation from cultivation to meadow starts at the beginning of the 20th century [44]. Our results are also discrepant, not the transformation processes, with those contributed by García Ruiz et al. [51] for the Spanish Central Pyrenees as a whole, in which the proportion of land area between cultivation and meadows goes from 7.33 in 1950 to 0.14 in 1991. Regarding the results of Fanlo et al. [52], in the Pyrenees of Lleida, similar processes are observed with a crop/meadow ratio of 2.34 in 1956 and the practical disappearance of the crop in 2000. The meadows pass from $13.99 \%$ of the surface to $11.28 \%$ not directly comparable for being the year 2000 and for not making reference to the changes of crop to meadow in 1986. 
Regarding the transformations or maintenance of crops and meadows in the period 1956-1986, there are relations with the characteristics and location of the parcels (Tables 3 and 4). As noted above, the characteristics of the 1956 meadows and crops parcels are within the same range of values. In spite of this, the meadows present higher average values in altitude, slope, orientation $E$ and $S$, and lower in radiation and number of parcels with terrace but not in surface, minor diameter, distance to the communication routes, and contiguity with pasture and forest polygons (Table 2). In fact, excluding parcels with terraces of very steep slopes or terraces of high areas of traditional agricultural use, crops and meadows alternated on the same parcel or were even mixed use $[39,48]$. Given these characteristics, the parcels that have been transformed from cultivation to meadow compared to those that have made it to pasture and forest have greater surface area, minor diameter and potential radiation, lower altitude and slope, majority orientation to $\mathrm{N}$ and $\mathrm{W}$, are closer to the communication routes, and the majority have no terrace. In the case of the meadows, those of lower altitude and slope have been maintained, with a majority orientation to the $\mathrm{N}$, closer to the roads and in greater proportion without terrace neither contiguity with pasture and forest. The characteristics of surface, minor diameter, altitude, slope, distance to the communication routes, and absence of terrace are decisive, in both cases, for the transition of the management of the meadows manually in 1956 [39] to the total mechanization of the work observed in 1986 [41,43,53]. On the contrary, the orientation and radiation, despite showing differences in some cases, do not allow a clear interpretation.

However, these parameters that are related to the change to pasture and forest are not independent. In this sense, the higher altitude and slope would have to be linked to the difficulty of establishing mechanized access tracks since they had been cultivated or meadow in 1956 when access was by means of cavalries. This is supported by the absence of differences between the meadow and crop parcels with respect to the distance to the communication routes in 1956 and the differences in 1986 when the access roads had already been built (Table 2). Lasanta [53] and Tasser and Tappeiner [54] also identify the lack of access as a priority factor in the transit from cultivation or meadow to pasture and forest. Likewise, the terraces built for the cultivation on slopes of steep slopes are related to the small area and smaller diameter and, therefore, are not suitable for mechanization. This abandonment of terraced cultivation occurs on similar dates in comparable mountain valleys, as other authors also point out $[43,51,55]$.

Regarding meadow parcels, it is observed that those that are contiguous with pasture and forest polygons have been transformed into pasture and forest in a greater proportion than those that do not come into direct contact. On the contrary, this situation is not detected in the transformation of the cultivation parcels to meadow or pasture and forest. This fact also occurs when no differences have been found between meadow and crop parcels in 1956 in relation to contiguity with pasture and forest. It is difficult to compare with studies of other territories of similar characteristics where meadows and crops have coexisted and the contiguity with pasture and forest polygons is contemplated. Both facts could be related to the grouped arrangement in the form of contiguous terraces of the cultivation parcels and more dispersed in the case of meadows.

- 1986-2016

After the notable increase in the hay meadows between 1956 and 1986, the decreasing evolution of the meadows between 1986 and 2016 is quantitatively important. The net balance assumes that, of the 1655 hectares mapped in 1986, 978 hectares (59.11\%) were passed in 2016. The transformations of the most relevant meadows in this period are pasture and forest $(34.89 \%)$ and urbanized land $(6.04 \%)$, and the cultures are anecdotal. The process is common to other areas of mountain meadows, but the times are not always coincident [46,55-57].

When considering the changes to pasture and forest or persistence of the meadows, it is observed that the parcels that have been maintained as a meadow are those of greater surface area, minor diameter and radiation, lower altitude, slope and distance to the communication routes, mainly oriented to the $\mathrm{N}$ and $\mathrm{E}$, and lower proportion of terraces (Tables 3 and 4). Since practically all the meadow parcels in 1986 were mechanized, the surface reduction occurs in the most unfavorable. 
However, this is not produced exclusively by the lower agronomic aptitude but by the conjunction of several factors [16].

First of all, it should be noted that, in this area of the Pyrenees, unlike other regions in Europe [7, 29,44,47,58-62], there has been no intensification (sowing, irrigation, fertilization, etc.) on the part of the meadows that have allowed an increase in productivity [63] that compensates for forage production derived from the reduction of the surface. Consequently, it is possible to think that the decrease in the area of meadows is linked to the downtrend of the forage needs conserved for the period of housing. The estimated reduction in this period is $60 \%$ of the cattle [64-67].

The changes that have occurred in the structure of livestock farms also influence the reduction in the number and total area of hay meadows. The reduction in the number of farms and the increase in their surface area and in the herd size has meant simplification of management $[44,68]$. These management changes have been directed towards grazing meadows to the detriment of mowing or the alternation between grazing and mowing. The transformation of the hay meadow to pasture and forest is a secondary succession, with different paths and stages $[17,18,25]$, which depends on various factors but usually involves the progressive introduction of shrubs. Even if they are grazed, the lack of mowing allows the appearance of shrubs [55,69-71] and, therefore, the consequent decrease in the amount of pasture to feed the cattle between autumn and spring.

In relation to the evolution of the meadows as they present contiguity with polygons of pasture and forest, it is observed that it is greater in those that remain as a meadow than in those that evolve into pasture and forest. Inverse phenomenon to that found in other mountain areas $[70,72,73]$ and that may be related to parameters that have not been considered [74] as the tree border that traditionally accompanies the meadows of this area of the Pyrenees [75].

\section{Conclusions}

The most relevant changes in the use of hay meadows and crops between 1956 and 1986 are the general reduction of the area $(13.59 \%)$, the increase in the area of meadows $(301.58 \%)$, mainly to the detriment of crops, and the practical disappearance of crops. In the same period, there is an increase in the area of pastures $(112.92 \%)$, forests $(103.71 \%)$, urbanized lands $(217.02 \%)$, and the construction of water reservoirs, mainly in fields of meadows and crops. These transformations occur at the same time as agricultural mechanization, the construction of access roads, and the increase of cattle. The mechanization requirements regarding access (altitude, slope, and distance to the communication routes) and parcel management (surface, minor diameter, slope, and terracing) determine the transit to pasture and forest of those that could be exploited as cultivation or meadow with horses and manually. The effect of the contiguity of the meadow and crop parcels with grassland or forest areas in the transformations is detected in the case of meadows but not in the case of crops.

In the period from 1986 to 2016, there is a reduction in the area of meadows to $59.11 \%$ that occurs at the same time as the decrease in the total amount cattle and the simplification of the management of the meadows by decreasing the number of livestock holdings and increase its size. The transformation occurs, as in the previous period, in favor of pastures $(11.12 \%)$, forests $(23.77 \%)$, and urbanized land $(6.04 \%)$. Considering that, in 1986, the parcels were mechanized, those most unfavorable were transformed to pasture and forest according to the same parameters of the changes between 1956 and 1986. No effect is detected with respect to the contiguity of meadow parcels with pasture and forest areas in their transformation or maintenance.

Supplementary Materials: The following are available online at http://www.mdpi.com/2073-4395/10/3/329/s1, Table S1:Changes in land use in surface area (ha) and proportion of land area (\%) compared to the beginning of the 1956-1986 interval, Table S2: Changes in land use in surface area (ha) and proportion of land area (\%) compared to the beginning of the 1986-2016 interval. 
Author Contributions: All authors (Joaquín Ascaso, Ramón Reiné and Olivia Barrantes) have contributed to the different components of the work. All authors have read and agreed to the published version of the manuscript.

Funding: This work has been funded by the SOS Praderas project within the Interreg Sudoe Program 2014-2020 (European Regional Development Fund (ERDF)) through the Department of Rural Development and Sustainability of the Government of Aragon.

Acknowledgments: The authors are grateful for the technical collaboration of J. Domingo and M. Gartzia (cartography), for the administration of D. Guzmán of Department of Rural Development and Sustainability of the Government of Aragon and M. Escar for the English review.

Conflicts of Interest: The authors declare no conflict of interest.

\section{References}

1. Ocaña, M. Ensayo de planificación ganadera en Aragón; Institución Fernando el Católico, 671: Zaragoza, Spain, 1978; ISBN 84-00-03792-8.

2. Chocarro, C.; Reiné, R. El cultivo de los prados en el Pirineo. In Pastos del Pirineo. Capítulo; Fillat, F., García González, R., Gómez García, D., Reiné, R., Eds.; Consejo Superior de Investigaciones Científicas: Madrid, Spain, 2007; Volume 10, pp. 141-158. ISBN 978-84-00-08614-5.

3. Hejcman, M.; Hejcmanová, P.; Pavlů, V.; Beneš, J. Origin and history of grasslands in Central Europe-A review. Grass Forage Sci. 2013, 68, 345-363. [CrossRef]

4. Dengler, J.; Janišová, M.; Török, P.; Wellstein, C. Biodiversity of Palaearctic grasslands: A synthesis. Agric. Ecosyst. Environ. 2013, 182, 1-14. [CrossRef]

5. Peeters, A. Importance, evolution, environmental impact and future challenges of grasslands and grassland-based systems in Europe. Grassl. Sci. 2009, 55, 115-125. [CrossRef]

6. Bouty, C.; Barbottin, A.; Martin, P. Quel devenir des surfaces en prairie permanente sur un territoire de polyculture-élevage? Innov. Agron. 2014, 39, 67-82.

7. Huyghe, C.; Peeters, A.; De Vliegher, A. La prairie en France et en Europe. Colloque presentant les methodes et resultats du projet Climagie (metaprogramme ACCAF); INRA: Poitiers, France, 2015; pp. 13-23. Available online: https://hal.archives-ouvertes.fr/hal-01233899 (accessed on 10 January 2020).

8. Lambin, E.F.; Geist, H.J. Land use and land cover change: Local processes and global impacts. In Global Change-The IGBP Series; Springer: Berlin/Heidelberg, Germany, 2006; ISBN 978-3540322016.

9. Foley, J.A.; Defries, R.; Asner, G.P.; Barford, C.; Bonan, G.; Carpenter, S.R.; Chapin, F.S.; Coe, M.T.; Daily, G.C.; Gibbs, H.K.; et al. Global consequences of land use. Science 2005, 309, 570-574. [CrossRef] [PubMed]

10. Sleeter, B.M.; Sohl, T.R.; Loveland, T.R.; Auch, R.F.; Acevedo, W.; Drummondc, M.A.; Sayler, K.L.; Stehman, S.V. Land-cover change in the conterminous United States from 1973 to 2000. Glob. Environ. Chang. 2013, 23, 733-748. [CrossRef]

11. Lark, T.J.; Mueller, R.M.; Johnson, D.M.; Gibbsa, H.K. Measuring land-use and land-cover change using the U.S. department of agriculture's cropland data layer: Cautions and recommendations. Int. J. Appl. Earth Obs. Geoinf. 2017, 62, 224-235. [CrossRef]

12. Lomba, A.; Strohbach, M.; Jerrentrup, J.S.; Dauber, J.; Klimek, S.; McCracken, D.I. Making the best of both worlds: Can high-resolution agricultural administrative data support the assessment of High Nature Value farmlands across Europe? Ecol. Indic. 2017, 72, 118-130. [CrossRef]

13. Bernués, A. Ganadería de montaña en un contexto global: Evolución, condicionantes y oportunidades. Pastos 2007, 37, 133-175.

14. García Martínez, A.; Olaizola, A.; Bernués, A. Trajectories of evolution and drivers of change in European mountain cattle farming systems. Animal 2009, 3, 152-165. [CrossRef]

15. Navarro, L.; Pereira, H. Rewilding Abandoned Landscapes in Europe. In Rewilding European Landscapes; Pereira, H., Navarro, L., Eds.; Springer: Cham, Switzerland, 2015. [CrossRef]

16. Pierik, M.E.; Gusmeroli, F.; Della Marianna, G.; Tamburini, A.; Bocchi, S. Meadows species composition, biodiversity and forage value in an Alpine district: Relationships with environmental and dairy farm management variables. Agric. Ecosyst. Environ. 2017, 244, 14-21. [CrossRef]

17. Pavlů, L.; Pavlı̊, V.; Gaisler, J.; Hejcman, M.; Mikulkaa, J. Effect of long-term cutting versus abandonment on the vegetation of a mountain hay meadow (Polygono-Trisetion) in Central Europe. Flora Morphol. Distrib. Funct. Ecol. Plants 2011, 206, 1020-1029. [CrossRef] 
18. Pruchniewicz, D. Abandonment of traditionally managed mesic mountain meadows affects plant species composition and diversity. Basic Appl. Ecol. 2017, 20, 10-18. [CrossRef]

19. McDonald, D.; Crabtree, J.R.; Wiesinger, G.; Dax, T.; Stamou, N.; Fleury, P.; Gutierrez Lazpita, J.; Gibon, A. Agricultural abandonment in mountain areas of Europe: Environmental consequences and policy response. J. Environ. Manag. 2000, 59, 47-69. [CrossRef]

20. Niedrist, G.; Tasser, E.; Lüth, C.; Dalla Via, J.; Tappeiner, U. Plant diversity declines with recent land use changes in European Alps. Plant Ecol. 2009, 202, 195-210. [CrossRef]

21. Stoate, C.; Báldi, A.; Beja, P.; Boatman, N.D.; Herzon, I.; van Doorn, A.; de Snoo, G.R.; Rakosy, L.; Ramwell, C. Ecological impacts of early 21st century agricultural change in Europe-A review. J. Environ. Manag. 2009, 91, 22-46. [CrossRef]

22. Zimmermann, P.; Tasser, E.; Georg Leitinger, G.; Tappeiner, U. Effects of land-use and land-cover pattern on landscape-scale biodiversity in the European Alps. Agric. Ecosyst. Environ. 2010, 139, 13-22. [CrossRef]

23. Tasser, E.; Walde, J.; Tappeiner, U.; Teutsch, A.; Noggler, W. Land-use changes and natural reforestation in the Eastern Central Alps. Agric. Ecosyst. Environ. 2007, 118, 115-129. [CrossRef]

24. Prévosto, B.; Kuiters, L.; Bernhardt-Römermann, M.; Dölle, M.; Schmidt, W.; Hoffmann, M.; Van Uytvanck, J.; Bohner, A.; \& Kreiner, D.; Stadler, J.; et al. Impacts of Land Abandonment on Vegetation: Successional Pathways in European Habitats. Folia Geobot. 2011, 46, 303-325. [CrossRef]

25. Schirpke, U.; Kohler, M.; Leitinger, G.; Fontana, V.; Tasser, E.; Tappeiner, U. Future impacts of changing land-use and climate on ecosystem services of mountain grassland and their resilience. Ecosyst. Serv. 2017, 26, 79-94. [CrossRef]

26. Tokarczyk, N. Forest encrochachment on temperate mountain meadows. Scale, drivers and current research directions. Geogr. Pol. 2017, 90, 463-480. [CrossRef]

27. Buitenwerf, R.; Sandel, B.; Normand, S.; Mimet, A.; Svenning, J.C. Land surface greening suggests vigorous woody regrowth throughout European semi-natural vegetation. Glob. Chang. Biol. 2018. [CrossRef]

28. Van Vliet, J.; de Groot, H.L.F.; Rietveld, P.; Verburg, P.H. Manifestations and underlying drivers of agricultural land use change. Landsc. Urban Plan. 2015, 133, 24-36. [CrossRef]

29. Peeters, A. Environmental impacts and future challenges of grasslands and grassland-based livestock production systems in Europe. In Grassland: A Global Resource Perspective; Ghosh, P.K., Mahanta, S.K., Singh, J.B., Pathak, P.S., Eds.; International Grassland Congress. Range Management Society of India: Jhansi, India, 2015; Available online: https://www.researchgate.net/publication/287489163_Environmental_impacts_ and_future_challenges_of_grasslands_and_grassland-based_livestock_production_systems_in_Europe (accessed on 10 January 2020).

30. IEEP. Alterra 2010. Reflecting Environmental Land Use Needs into EU Policy: Preserving and Enhancing the Environmental Benefits of "Land Services": Soil Sealing, Biodiversity Corridors, Intensification/Marginalisation of Land Use and Permanent Grassland; Final Report to the European Commission, DG Environment on Contract ENVB1/ETU/2008/0030; Institute for European Environmental policy/Alterra Wageningen UR: Wageningen, The Netherlands, 2010; Available online: https:/edepot.wur.nl/160020 (accessed on 10 January 2020).

31. Opermann, R.; Beaufoy, G.; Jones, G. High Nature Value Farming in Europe. 35 European Countries-Experiences and Perspectives; Ubstadt-Weiher, A., Ed.; Verlag regionalkultur: Ubstadt-Weiher, Germany, 2012; Available online: http://www.verlag-regionalkultur.net/xtc/product_info.php?info=p781_High-NatureValue-Farming-in-Europe.html (accessed on 10 January 2020).

32. Cattan, A. La préservation des prairies dans la PAC: Les raisons d'une illusion. Courrier de l'environement de l'INRA 2014, 64, 91-103. Available online: https://hal.archives-ouvertes.fr/hal-01222601/file/Courrier64Cattan-28--10-14.pdf (accessed on 10 January 2020).

33. García de la Fuente, L.; Guzmán, D.; Mora, A.; Nobre, S.; Brau-Nogué, C. Informe de iniciativas existentes para promover la siega a través de los PDR y los instrumentos de la nueva PAC en la UE. Proyecto Interreg SUDOE "SOS PRADERAS", INDUROT-Universidad de Oviedo. In Proceedings of the 27th European Grassland Federation General Meeting, Cork, Irlanda, 17-21 June 2017; Available online: https: //www.sospraderas.eu/documentacion/ (accessed on 10 January 2020).

34. Keenleyside, C.; Beaufoy, G.; Tucker, G.; Jones, G. High Nature Value farming throughout EU-27 and Its Financial Support under the CAP. Report Prepared for DG Environment, Contract No ENV B.1/ETU/2012/0035; Institute for European Environmental Policy: London, UK, 2014; Available 
online: https://ieep.eu/uploads/articles/attachments/2e7adcbd-ba75--44db-89e6--0e1669076607/HNV_and_ CAP_Full_Report.pdf?v=63664509849 (accessed on 10 January 2020).

35. IDEARAGÓN. Infraestructura de datos espaciales de Aragón; Instituto Geográfico de Aragón. Gobierno de Aragón: Zaragoza, Spain, 2019; Available online: http://idearagon.aragon.es/ (accessed on 10 January 2020).

36. Felicísimo, A.M. Modelos Digitales del Terreno. Introducción y aplicaciones en las ciencias ambientales; Pentalfa Ediciones: Oviedo, Spain, 1994; ISBN 8478484752.

37. Collantes, F. La ganadería de montaña en España, 1865-2000: Historia de una ventaja comparativa anulada. Hist. Agrar. 2003, 31, 141-167.

38. Clar, E.; Pinilla, V. Path Dependence and the Modernisation of Agriculture: A Case Study of Aragon, $1955-85$. Rural Hist. 2011, 22, 251-269. [CrossRef]

39. Daumas, M. La vie rurale dans le haut Aragon oriental; CSIC: Madrid, Spain, 1976.

40. Manrique, E.; Revilla, R.; Sáez, E. Características estructurales del sector agro-ganadero de la comarca de Ribagorza; Institución Fenando el Católico, publ. n 1087: Zaragoza, Spain, 1987; ISBN 84-00-06527-I.

41. Olaizola, A. Viabilidad económica de sistemas ganaderos de montaña en condiciones de competencia en el uso de factores productivos. Análisis de la ganadería en un valle pirenaico característico mediante técnicas multivariante y de optimización. Ph.D. Thesis, Universidad de Zaragoza, Instituto de Estudios Altoaragoneses, Huesca, Spain, 1991.

42. Malandra, F.; Vitali, A.; Urbinati, C.; Garbarino, M. 70 Years of Land Use/Land Cover Changes in the Apennines (Italy): A Meta-Analysis. Forests 2018, 9, 551. [CrossRef]

43. Mottet, A.; Ladet, S.; Coqué, N.; Gibon, A. Agricultural land-use change and its drivers in mountain landscapes: A case study in the Pyrenees. Agric. Ecosyst. Environ. 2006, 114, 296-310. [CrossRef]

44. Sheeren, D.; Lefèbvre, J.; Ladet, S.; Balent, G.; Brame, A.; Bray, F.; Capitaine, M.; Gibon, A.; Lasseur, R.; Lasseur, J.; et al. Coévolution des paysages et des activités agricoles dans différents territoires d'élevage des montagnes françaises: Entre intensification et déprise agricole. Fourrages 2015, 222, 103-113.

45. García Manteca, P.; García de la Fuente, L.; Aguiar, C.; Azevedo, J.; Reiné, R.; Ascaso, J.; Guzmán, D.; Díaz, T.E. Mountain hay meadows: Assessing the loss of surfaces and ecosystem services in Iberian areas. Restoration in the Era of Climate Change. In Proceedings of the SER Europe Conference, Reykjavik, Iceland, 9-13 September 2018; Available online: https://www.sospraderas.eu/wp-content/uploads/2019/07/Abstract-SER_GT1.pdf (accessed on 10 January 2020).

46. García Manteca, P.; García de la Fuente, L.; González Iglesias, V.; Díaz González, T.E. Cartografía de los usos del suelo agropastorales en el Parque Nacional de Picos de Europa en tres periodos anuales. Bol. Cien. Nat. y Tecnol. R.I.D.E.A. 2019, 54, 195-204.

47. Hinojosa, L.; Tasser, E.; Rüdisser, J.; Leitinger, G.; Schermer, M.; Lambin, E.F.; Tappeiner, U. Geographical heterogeneity in mountain grasslands dynamics in the Austrian-Italian Tyrol region. Appl. Geogr. 2019, 106, 50-59. [CrossRef]

48. Fillat, F. De la trashumancia a las nuevas formas de ganadería extensiva. Estudio de los Valles de Ansó, Hecho y Benasque. Ph.D. Thesis, Universidad Politécnica de Madrid, Madrid, Spain, 1980.

49. Balent, G.; Gibon, A. Transformations des pratiques collectives dans les systèmes pastoraux des Pyrénées centrales: Caractéristiques et enjeux. Aménagement et Nature 1992, 108, 10-13.

50. Balent, G.; Duru, M. Influence des modes d'explotation sur les caractéristiques et l'évolution des surfaces pastorales: Cas des Pyrénées centrales. Agronomie 1984, 4, 113-124. [CrossRef]

51. García Ruiz, J.M.; Lasanta, T.; Ruiz Flaño, P.; Ortigosa, L.; White, S.; González, C.; Marti, C. Land-use changes and sustainable development in mountain areas: A case study in the Spanish Pyrenees. Landsc. Ecol. 1996, 11, 267-277. [CrossRef]

52. Fanlo, R.; Chocarro, C.; Massip, G.; Castelló, M. Cambios de uso en las superficies pastorales de un municipio de montaña en los últimos 50 años: El caso de Espot (Lleida). In Producción de pastos, forrajes y céspedes; Chocarro, C., Santiveri, F., Fanlo, R., Bovet, I., Lloveras, J., Eds.; Ediciones Universitat de Lleida: Lérida, Spain, 2002; pp. 591-596. ISBN 84-8409-145-7.

53. Lasanta, T. The process of desertion of cultivated areas in the Central Spanish Pyrenees. Pirineos 1988, 132, $15-36$.

54. Tasser, E.; Tappeiner, U. Impact of land use changes on mountain vegetation. Appl. Veg. Sci. 2002, 5, 173-184. [CrossRef] 
55. Houet, T.; Ribiere, O.; Vacquié, L.; Vidal, F.; Galop, D. Caractérisation de la fermeture des paysages dans les Pyrénées depuis les années 1940-Application sur le Haut-Vicdessos. Sud-Ouest Européen 2012, 33, 116-126. [CrossRef]

56. Cocca, G.; Sturaro, E.; Gallo, L.; Ramanzin, M. Is the abandonment of traditional livestock farming systems the main driver of mountain landscape change in Alpine areas? Land Use Policy 2012, 29, 878-886. [CrossRef]

57. Vacquié, L. Modélisation prospective et échelles spatiales en montagne:application aux Pyrénées françaises; Géographie; Université Toulousele Mirail-Toulouse II: Toulouse, France, 2015; Available online: https://tel.archivesouvertes.fr/tel-01275936 (accessed on 10 January 2020).

58. Marini, L.; Scotton, M.; Klimek, S.; Isselstein, J.; Pecile, A. Effects of local factors on plant species richness and composition of Alpine meadows. Agric. Ecosyst. Environ. 2007, 119, 281-288. [CrossRef]

59. Marini, L.; Fontana, P.; Klimekc, S.; Battistia, A.; Gastonb, K.J. Impact of farm size and topography on plant and insect diversity of managed grasslands in the Alps. Biol. Conserv. 2009, 142, 394-403. [CrossRef]

60. Graf, R.; Müller, M.; Korner, P.; Jenny, M.; Jenny, L. 20\% loss of unimproved farmland in 22 years in the Engadin, Swiss Alps. Agric. Ecosyst. Environ. 2014, 185, 48-58. [CrossRef]

61. Scotton, M.; Sicher, L.; Kasal, A. Semi-natural grasslands of the Non Valley (Eastern Italian Alps): Agronomic and environmental value of traditional and new Alpine hay-meadow types. Agric. Ecosyst. Environ. 2014, 197, 243-254. [CrossRef]

62. Bosshard, A. Recul des prairies a fromental Arrhenatheretum et consequences sur la biodiversite. Recherche Agronomique Suisse 2015, 6, 20-27.

63. Reiné, R.; Chocarro, C.; Juárez, A.; Barrantes, O.; Ferrer, C.; Broca, A. Características de la producción herbácea en los prados de siega del Pirineo de Huesca. In La multifuncionalidad de los pastos: Producción ganadera sostenible y gestión de ecosistemas; Reiné, R., Barrantes, O., Broca, A., Ferrer, C., Eds.; Sociedad Española para el Estudio de los Pastos: Huesca, Spain, 2009; pp. 101-107. ISBN 978-84-612-9337-7.

64. García Martínez, A. Dinámica reciente de los sistemas de vacuno en el Pirineo Central y evaluación de sus posibilidades de adaptación al entorno socio-económico. Ph.D. Thesis, Universidad de Zaragoza, Zaragoza, Spain, 2007. Available online: https://zaguan.unizar.es/record/2013/files/ (accessed on 10 January 2020).

65. Bernués, A.; Olaizola, A. La ganadería en los Pirineos: Evolución, condicionantes y oportunidades. In Coord-Los Pirineos. Geografía, Turismo, Agricultura, Cooperación transfronteriza y Derecho; Universidad del País Vasco: Leiola, Spain, 2012; pp. 29-67. Available online: https:/citarea.cita-aragon.es/citarea/bitstream/10532/ 2142/1/2012_342.pdf (accessed on 10 January 2020).

66. Censo Agrario. 1989, 1999, 2009. Instituto Nacional de Estadística. Available online: https://www.ine.es/ (accessed on 10 January 2020).

67. Directorios Ganaderos. 2008-2013. Departamento de Agricultura, Ganadería y Medio Ambiente; Gobierno de Aragón: Zaragoza, Spain, 2014. Available online: https:/www.aragon.es/en/-/estadisticas-ganaderas (accessed on 10 January 2020).

68. Lasanta, T.; Arnáez, J.; Pascual, N.; Ruiz Flaño, P.; Errea, M.P.; Lana Renault, N. Space-time process and drivers of land abandonment in Europe. Catena 2017, 149, 810-823. [CrossRef]

69. Julien, M.P.; Alard, D.; Balent, G. Patterns of ash (Fraxinus excelsior L.) colonization in mountain grasslands: The importance of management practices. Plant Ecol. 2006, 183, 177-189. [CrossRef]

70. Gartzia, M.; Alados, C.L.; Pérez Cabello, F. Assessment of the effects of biophysical and anthropogenic factors on woody plant encroachment in dense and sparse mountain grasslands based on remote sensing data. Prog. Phys. Geogr. 2014, 38, 201-217. [CrossRef]

71. Nadal Romero, E.; Lasanta, T.; Cerdà, A. Integrating Extensive Livestock and Soil Conservation Policies in Mediterranean Mountain Areas for Recovery of Abandoned Lands in the Central Spanish Pyrenees. A Long-Term Research Assessment. Land Degrad. Dev. 2016, 29, 262-273. [CrossRef]

72. Lasanta, T.; Vicente-Serrano, S.M. Cambios en la cubierta vegetal en el Pirineo aragonés en los últimos 50 años. Pirineos 2007, 162, 125-154. [CrossRef]

73. Velli, A.; Pirola, A.; Ferrari, C. Evaluating landscape changes using vegetation and land-use maps: An integrated approach. Landsc. Res. 2018, 44, 768-781. [CrossRef] 
74. Gellrich, M.; Baur, P.; Koch, B.; Zimmermann, N.E. Agricultural land abandonment and natural forest re-growth in the Swiss mountains: A spatially explicit economic analysis. Agric. Ecosyst. Environ. 2007, 118, 93-108. [CrossRef]

75. Chocarro, C.; Fanlo, R.; Fillat, F.; Villar, L. Sur les communautes prairiales et leur gestion dans duex vallées de Pyrénées centrales espagnoles. Colloques Phytosociologiques 1990, 14, 457-472. 